\title{
PENINGKATAN KETERAMPILAN SOSIAL ANAK USIA DINI MELALUI PERMAINAN TRADISIONAL BABANCAKAN DI POS PAUD MELATI O3
}

\author{
Ambar Sri Handayani ${ }^{1}$ \\ ${ }^{1}$ PAUD Melati 03 Cimahi \\ 1'ambara_srihandayani@yahoo.co.id
}

\begin{abstract}
This research raises the problem of: Early Childhood Education Teacher Education Study Program titled "Improving Early Childhood Social Skills Through Traditional Games Babancakan At Pos Paud Melati O3" .The goal to be achieved through this research is to know and describe: In general, research aims to "To know the description of objective conditions of social intelligence in POS PAUD Melati 03. To know the process of implementation of traditional games in POS PAUD Melati 03 to improve and motivate the child in improving social skills. To know the results of traditional games in order to improve the social skills of children early age in POS PAUD Melati 03 ". This research is carried out with the approach used in this research is qualitative research approach. Sugiyono (2009: 2122). The source of this research data is the child of World Kid Students Cimahi. While the sample amounted to 30 children as well as used as a sample refresentatif are 2 teachers and 5 children to be a case. The research data was collected by using instrument in the form of interview guide and observation guideline. The use of traditional games to improve children's social intelligence in this study was conducted through two observations. From the results of observations that have been done there is a fairly good improvement on the development of social skills of children in every action on each activity. The results of observations from the improvement of the development of Child Social Skills are seen by comparing the results of each assessment indicator achieved either by the child on the initial observation with the results of each activity. Increases not only occur in every assessment indicator, but every child in POS PAUD Melati 03
\end{abstract}

Key Words Social Skills Babancakan Traditional Games activities.

\begin{abstract}
Abstrak
Penelitian ini mengangkat permasalahan tentang : Program Studi Pendidikan Guru Pendidikan Anak usia Dini dengan judul "Peningkatan Keterampilan Sosial Anak Usia Dini Melalui Permainan Tradisional Babancakan Di Pos Paud Melati O3 “.Tujuan yang ingin dicapai melalui penelitian ini adalah untuk mengetahui dan mendeskripsikan : Secaraumum,penelitianbertujuan untuk"Untuk mengetahui gambaran kondisi obyektif kecerdasan sosial di POS PAUD Melati 03. Untuk mengetahui proses pelaksanaan permainan tradisional di POS PAUD Melati 03 untuk meningkatkan dan motivasi anak dalam peningkatan keterampilan sosial.Untuk mengetahui hasil permainan tradisional babancakan dalam rangka peningkatan keterampilan sosial anak usia dini di POS PAUD Melati 03". Penelitian ini dilaksanakan dengan pendekatan kualitatif. Sumber data penelitian ini adalah anak-anak Kober Dunia Anak Cimahi. Sedangkan sampel berjumlah 30 orang anak serta dijadikan sampel refresentatif adalah 2 orang guru dan 5 anak untuk menjadi kasus.Data penelitian dikumpulkan dengan menggunakan instrumen berupa pedoman wawancara dan pedoman observasi. Penggunaan permainan tradisional untuk meningkatkan kecerdasan sosial anak dalam penelitian ini dilaksanakan dengan melalui dua kali observasi. Dari hasil observasi yang telah dilakukan terdapat peningkatan yang cukup baik pada pengembangan Keterampilan sosial anak dalam setiap tindakan pada setiap kegiatannya. Hasil observasi dari peningkatan pengembangan Keterampilan sosial anak
\end{abstract}


dilihat dengan membandingkan hasil setiap indikator penilaian yang dicapai baik oleh anak pada observasi awal dengan hasil dari setiap kegiatan. Peningkatan tidak hanya terjadi pada setiap indikator penilaian, namun setiap anak di POS PAUD Melati 03 pun mengalami pengembangan Keterampilan sosial melalui kegiatan Permainan Tradisional Babancakan.

Kata Kunci : Keterampilan Sosial, Permainan Tradisional

\section{PENDAHULUAN}

Pendidikan anak usia dini merupakan salah satu bentuk penyelenggaraan pendidikan yang menitikberatkan pada peletakan dasar beberapa arah, yaitu pertumbuhan dan perkembangan fisik, kecderdasan dan social emosional. Adapun aspek yang dikembangkan dalam pendidikan anak usia dini di dalam kurikulum 2013 PAUD adalah aspek pengembangan perilaku dan pembiasaan yang meliputi nilai moral dan agama, bahasa, kognitif, motorik, sosial emosional dan seni. Aspek-aspek tersebut baru akan berkembang dengan adanya pengaruh dari lingkungan anak itu berada. pada usia ini kemampuan-kemampuan dasar manusia terbangun dan menjadi pondasi bagi pertumbuhan dan perkemnangan selanjutnya, termasuk perkembangan moral dan perilaku yang menjadi dasar pembentukan karakter.

Dalam lingkungan pendidikan formal, anakanak harus berinteraksi dan bernegosiasi dengan teman-temannya yang memiliki kompetensi social, minat, kemampuan, dan gaya interaksi yang berbeda-beda. Tidak sedikit anak-anak meminta guru mereka untuk membantunya menghadapi berbagai tantangan yang baru ini. Jika anak-anak tidak diajari untuk berinteraksi dengan baik, bias dipastikan suasana kelas tidak akan kondusif dan akibatnya akan mengganggu konsentrasi belajar mereka. Kemampuan berinteraksi secara positif sebagaimana keterampilan dan pengetahuan akademik lainnya, turut berpengaruh terhadap keberhasilan mereka dalam menjalani kehidupan yang sebenarnya.

Keterampilan sosial, dari yang dikemukakan oleh Fatimah, (2006 : 94) berpendapat bahwa keterampilan sosial adalah kemampuan mengatasi segala permasalahan yang timbul sebagai hasil dari interaksi dengan lingkungan. Anak-anak yang mempunyai kesadaran diri yang kuat siap untuk belajar hidup nersama dengan orang lain. Kemampuan berkomunikasi perilaku-perilaku yang dipelajari, yang digunakan individu dalam interpersonal untuk memperoleh pengukuhan dari lingkungan.Dengan demikian, keterampilan sosial bukan sesuatu yang dibawa dari lahir tetapi perilaku yang dipelajari dari kehidupan seharihari anak.Pelajaran yang diperoleh baik dari lingkungan keluarga maupun lingkungan sekitar, seperti teman sebaya, orang dewasa disekitarnya yang mendorong anak untuk beradaptasi dengan lingkungan.

Dengan mengunakan metode pembelajaran yang sesuai dengan kurikulum dan perkembangan anak usia dini akan didapat hasil yang maksimal baik dalam hal akademis maupun psikologis anak. Penggunaan metode pembelajaran yang menyenangkan untuk anak akan membuat anak senang dalam belajar dan anak tidak merasa dipaksa dalam belajar.

Yunus (1981; 27) mengungkapkan bahwa permainan tradisional sering disebut juga permainan rakyat, merupakan permainan yang tumbuh dan berkembang pada masa lalu terutama tumbuh di masyarakat pedesaan.Permainan tradisional tumbuh dan berkembang berdasarkan kebutuhan masyarakat setempat.

Permainan tradisional sarat akan nilai-nilai budaya yang tinggi sehingga sangat dapat diajarkan kepada anak. Ciri khas dari permainan tradisional adalah sebagai berikut: 1) permainan tradisional dalam bermainnya memerlukan tatap muka antar pemain; 2) banyak bergerak; dan 3) dilakukan bersama-sama. Permainan tradisional dilakukan secara bersama-sama sehingga membutuhkan tatap muka antar pemainnya, hal ini dapat menjalin interaksi social antar pemainnya.Dari interaksi itulah anak dapat mengembangkan kemampuan bersosial dengan teman sebaya atau dengan lingkungan, melatih 


\section{JURNAL CERIA}

ISSN : 2614-6347 (Print) 2614-4107 (Online)

Vol.1 | No.3 | Mei 2018

kreativitas anak, mengembangkan kemampuan motoric anak, melatih jiwa sportivitas anak, mempererat persahabatan, dan melatih anak untuk bekerjasama dengan kelompok.

Bermain merupakan suatu sarana yang memungkinkan anak berkembang secara optimal.Bermain dapat mempengaruhi seluruh atau semua aspek perkembangan dengan memberikan kesempatan pada anak untuk belajar tentang dirinya sendiri, keluarga, teman sebaya, dan lingkungan disekitar anak.Melalui bermain anak juga dapat mengembangkan kemampuan sosialnya, seperti membina hubungan dengan anak lain, bertingkah laku sesuai dengan tuntutan masyarakat, menyesuaikan diri dengan teman sebaya, dapat memahami tingkah lakunya sendiri, dan faham bahwa setiap perbuatan ada konsekuensinya.

Berdasarkan pernyataan diatas, maka penelitian ini memfokuskan pada kajian "Peningkatan Keterampilan Sosial Anak Usia Dini Melalui Permainan Tradisional Babancakan Di Pos Paud Melati O3".

\section{Tinjauan Pustaka \\ Perkembangan Sosial}

Menurut Plato secara potensial (fitrah) manusia dilahirkan sebagai makhluk sosial (zoon politicori). Syamsuddin

$(1995: 105)$ mengungkapkan bahwa "sosialisasi adalah proses belajar untuk menjadi makhluk sosial", sedangkan menurut Loree (1970:86) "sosialisasi merupakan suatu proses di mana individu (terutama) anak melatih kepekaan dirinya terhadap rangsangan-rangsangan sosial terutama tekanan-tekanan dan tuntutan kehidupan (kelompoknya) serta belajar bergaul dengan bertingkah laku, seperti orang lain di dalam lingkungan sosialnya".

Muhibin (1999:35) mengatakan bahwa perkembangan sosial merupakan proses pembentukan social self (pribadi dalam masyarakat), yakni pribadi dalam keluarga, budaya, bangsa, dan seterusnya. Adapun Hurlock (1978:250) mengutarakan bahwa perkembangan sosial merupakan perolehan kemampuan berperilaku yang sesuai dengan tuntutan sosial.
"Sosialisasi adalah kemampuan bertingkah laku sesuai dengan norma, nilai atau harapan sosial".

\section{Proses Perkembangan Sosial Anak Usia Dini}

Untuk menjadi individu yang mampu bermasyarakat diperlukan tiga proses sosialisasi. Proses sosialisasi ini tampaknya terpisah, tetapi sebenarnya saling berhubungan satu sama lainnya, sebagaimana yang dikemukakan oleh Hurlock (1978), yaitu sebagai berikut.

a. Belajar untuk bertingkah laku dengan cara yang dapat diterima masyarakat.

b. Belajar memainkan peran sosial yang ada di masyarakat.

c. Mengembangkan sikap/tingkah laku sosial terhadap individu lain dan aktivitas sosial yang ada di masyarakat.

Pada perkembangannya, berdasarkan ketiga tahap proses sosial ini, individu akan terbagi ke dalam dua kelompok, yaitu kelompok individu sosial dan individu nonsosial. Kelompok individu sosial adalah mereka yang tingkah lakunya mencerminkan ketiga proses sosialisasi. Mereka mampu untuk mengikuti kelompok yang diinginkan dan diterima sebagai anggota kelompok. Adakalanya mereka selalu menginginkan adanya orang lain dan merasa kesepian apabila berada seorang diri. Selain itu mereka juga merasa puas dan bahagia jika selalu berada dengan orang lain. Adapun kelompok individu nonsosial, mereka adalah orang-orang yang tidak berhasil mencerminkan ketiga proses sosialisasi. Mereka adalah individu yang tidak tahu apa yang diharapkan kelompok sosial sehingga tingkah laku mereka tidak sesuai dengan harapan sosial. Kadang-kadang mereka tumbuh menjadi individu antisosial, yaitu individu yang mengetahui harapan kelompok sosial, tetapi dengan sengaja melawan hal tersebut.Akibatnya individu antisosial ini ditolak atau dikucilkan oleh kelompok sosial.

Selain kedua kelompok tadi, dalam perkembangan sosial ini adapula istilah individu yang introvert dan extrovert. Introvert adalah kecenderungan seseorang untuk menarik diri dari lingkungan sosialnya. Minat, sikap ataupun keputusan-keputusan yang diambil selalu didasarkan pada perasaan, pemikiran, dan 


\section{JURNAL CERIA}

ISSN : 2614-6347 (Print) 2614-4107 (Online)

Vol.1 | No.3 | Mei 2018

pengalamannya sendiri. Orang-orang dengan kecenderungan introvert, biasanya pendiam dan tidak membutuhkan orang lain karena merasa segala kebutuhannya bisa dipenuhi sendiri. Sedangkan extrovert adalah kecenderungan seseorang untuk mengarahkan perhatian ke luar dirinya sehingga segala minat, sikap, dan keputusan-keputusan yang diambilnya lebih ditentukan oleh peristiwa-peristiwa yang terjadi di luar dirinya.

Orang-orang extrovert biasanya cenderung aktif, suka berteman, dan ramah-tamah. Seorang ahli menyatakan introvert dan extrovert hanya merupakan suatu tipe dari reaksi yang ditunjukkan seseorang. Jika seseorang menunjukkan reaksi yang terus-menerus seperti itu atau sudah menjadi kebiasaan barulah bisa dianggap sebagai tipe kepribadiannya. Sementara ahli lain menyatakan bahwa suatu kepribadian yang sehat atau seimbang haruslah memiliki kedua kecenderungan ini. Dengan demikian, kebutuhan untuk berhubungan dengan lingkungan sosialnya serta kebutuhan akan prestasi dan refleksi diri keduanya bisa terpuaskan.

Ada dua puluh karakteristik yang dapat menggambarkan individu dengan penyesuaian diri baik, yaitu sebagai berikut.

a. Dapat menerima tanggung jawab sesuai dengan usianya.

b. Menikmati pengalamannya.

c. Mau menerima tanggung jawab sesuai dengan perannya. Apakah itu peran sebagai anggota kelompok, murid di sekolah atau sekadar peran kakak terhadap adiknya.

d. Mampu memecahkan masalah dengan segera.

e. Dapat melawan dan mengatasi hambatan untuk merasa bahagia.

f. Mampu membuat keputusan dengan kekhawatiran dan konflik yang minimum.

g. Tetap pada pilihannya sehingga ia menemukan bahwa pilihannya itu salah.

h. Merasa puas dengan kenyataan.

i. Dapat menggunakan pikiran sebagai dasar untuk bertindak, tidak untuk melarikan diri.

j. Belajar dari kegagalan tidak mencari alasan untuk kegagalannya.

k. Tahu bagaimana harus bekerja pada saat kerja dan bermain pada saat main.
1. Dapat berkata tidak pada situasi yang mengganggunya.

m. Dapat berkata ya pada situasi yang membantunya.

n. Dapat menunjukkan kemarahan ketika merasa terluka atau merasa haknya terganggu.

o. Dapat menunjukkan kasih sayang.

p. Dapat menahan sakit dan frustrasi bila diperlukan.

q. Dapat berkompromi ketika mengalami kesulitan.

r. Dapat mengonsentrasikan energinya pada tujuan.

s. Menerima kenyataan bahwa hidup adalah perjuangan yang tak ada habisnya.

t. Untuk menjadi individu dengan penyesuaian diri yang baik, seorang anak harus merasa bahagia dan mampu menerima dirinya. Untuk itu, sejak dini anak perlu diajak bersikap realistis terhadap diri dan kemampuannya.

\section{Konsep Keterampilaan Sosial}

Keterampilan sosial berasal dari kata keterampilan dan sosial. Kata keterampilan berasal dari kata "terampil" digunakan disini karena didalamnya terkandung suatu proses belajar, dari tidak terampil menjadi terampil. Kata sosial digunakan karena pelatihan ini bertujuan untuk mengajarkan satu kemampuan berinteraksi dengan orang lain. Keterampilan sosial maksudnya adalah pelatihan yang bertujuan untuk mengajarkan kemampuan berinteraksi dengan orang lain kepada individu-individu yang tidak terampil menjadi terampil berinteraksi dengan orang-orang disekitarnya.

Keterampilan sosial "Social Skills" merupakan bagian penting dari kemampuan hidup manusia. Tanpa memiliki keterampilan ini manusia tidak mulus dalam berinteraksi dengan orang lain, sehingga hidupnya kurang harmonis. Social skill atau keterampilan sosial memiliki penafsiran akan arti dan maknanya. Beberapa para ahli yang memberikan pendapatnya tentang keterampilan sosial sebagai berikut:

a. Merrel (2008), keterampilan sosial sebagai perilakuspesifik, inisiatif, mengarahkan pada hasil sosial yang diharapkan sebagai bentuk perilaku seseorang. 


\section{JURNAL CERIA}

ISSN : 2614-6347 (Print) 2614-4107 (Online)

Vol.1 | No.3 | Mei 2018

b. Combs \& Slaby (Gimpel dan Merrel,1998), keterampilan sosial adalah kemampuan berinteraksi dengan orang lain dalam konteks sosial dengan cara-cara yang khusus yang dapat diterima secara sosial maupun nilainilai dan di saat yang sama berguna bagi dirinya dan orang lain.

c. Libet dan Lewinsohn (Cartledge dan Milburn, 1995), keterampilan sosial sebagai kemampuan yang kompleks untuk menunjukkan perilaku yang baik dinilai secara positif atau negatif oleh lingkungan, dan jika perilaku itu tidak baik akan diberikan punishment oleh lingkungan.

d. Cartledge dan Milburn (1992: 8) menyatakan bahwa "social skills are one's or society member ability with establishing relationship with others and his problems solving ability with which a harmoniuous society can be achieved". Menurut definisi tersebut keterampilan sosial merupakan kemampuan seseorang atau warga masyarakat dalam mengadakan hubungan interaksi dengan orang lain dan kemampuan memecahkan masalah, sehingga memperoleh adaptasi yang harmonis di masyarakat maupun lingkungan sekolah.

Keterampilan sosial dapat membawa anak untuk lebih berani menyatakan diri, mengungkapkan setiap perasaan atau permasalahan yang dihadapi dan sekaligus menemukan penyelesaian yang adaptif, sehingga mereka tidak mencari pelarian ke hal-hal lain yang justru dapat merugikan diri sendiri dan orang lain.

Beberapa pendapat tersebut dapat disimpulkan bahwa keterampilan sosial adalah suatu kemapuan hidup manusia dalam dan segala aktifitas yang dilakukan dapat terterima secara baik dilingkungan sosial mereka serta keterampilan atau strategi yang digunakan untuk memulai ataupun mempertahankan suatu hubungan yang positif dalam interaksi sosial, yang diperoleh melalui proses belajar.

\section{Metode Penelitian}

Penelitian ini menggunakan metode deskriptif kualitatif, yaitu melakukan penelitian dengan tujuan ingin menggambarkan masalah dan melakukan analisis terhadap masalah.

Metode deskripsi merupakan metode penelitian non hipotesis, sehingga dalam langkah penelitiannya tidak perlu menentukan hipotesis. Dengan metode diatas, penulis akan menggambarkan mengenai implementasi kurikulum di POS PAUD Melati 03.

Untuk memperoleh data-data yang berkenaan dengan judul penelitian, penulis menggunakan teknik pengumpulan data sebagai berikut:

\section{Wawancara}

Yaitu percakapan yang dilakukan dua pihak, yaitu pewawancara (interviewer) yang mengajukan pertanyaan dan terwawancara (interviewee) yang memberikan jawaban dengan maksud tertentu yang berhubungan dengan masalah yang diteliti.Penulis melakukan wawancara dengan Ketua Kober dan staf pengajar di Kober tersebut.

2. Studi Pustaka

Yaitu penulis menggunakan buku-buku sebagai referensi yang sesuai

dengan judul penelitian (Suharsimi Arikunto, Prosedur Penelitian, (Jakarta: Rineka Cipta, 2010), hal 270)

3. Observasi

Yaitu penulis melakukan kunjungan ke tempat penelitian dan melakukan pengamatan yang berkaitan dengan tujuan penelitian tersebut.

4. Studi Dokumentasi

Dokumentasi adalah setiap bahan tertulis baik bersifat resmi ataupun tidak. Penulis berusaha memahami dan menganalisa dokumendokumen tertulis yang diperoleh dari tempat penelitian untuk selanjutnya dikembangkan pada bagian bab tertentu. Sedangkan instrumen pengumpulan data dalam penelitian ini yaitu:

a. Pedoman wawancara yang terdiri dari beberapa daftar pertanyaan yang berhubungan dengan judul penelitian.

b. Pedoman observasi. Pedoman tersebut berisi mengenai gambaran nyata yang akan dijadikan objek penelitian diantaranya adalah bagaimana kondisi objek yang akan diteliti tersebut. 
Pedoman dokumentasi

\section{Pembahasan}

Menurut Guru Tahap pertama, yaitu pelaksanaan sebelum melaksanakan pengembangan Keterampilan sosial untuk meningkatkan Keterampilan Sosial anak usia dini . Hal ini dilakukan untuk mengetahui kondisi awal POS PAUD Melati 03 sebelum mendapat pembelajaran . Pelaksanaan dilakukan selama 1 hari. Pedoman pelaksanaan yang digunakan terdiri dari 7 pertanyaan observasi yang telah teruji kevalidannya serta reabilitasnya. Adapun hasil pelaksanaannya dapat dilihat pada pokok bahasan hasil penelitian.

Tahap kedua yaitu pelaksanaan pembelajaran dengan Permainan Tradisional Babancakan dalam pengembangan Keterampilan sosialterhadap anak POS PAUD Melati 03 dengan Permainan Tradisional Babancakan . Pembelajaran dilaksanakan selama 1 kali pertemuan, dengan durasi tiga puluh menit dalam pertemuannya Berikut gambaran pelaksanaan pembelajaran :Anak mampu beriteraksi, dan menunjukkan reaksi emosi yang wajar, mengenal tagungjawab, mulai menunjukkan kemandirian, disiplin, dan percaya diri. Lamanya waktu yang digunakan dalam proses belajar adalah hari Senin dan rabu dimulai dari pukul 07.30 - 10.00 WIB. Dengan alokasi waktu pembelajaran POS PAUD Melati 03 yaitu kegiatan pembukaan selama 30 menit, dilanjutkan kegiatan inti selama 60 menit, kemudian istirahat selama 30 menit dan diakhiri penutupan selama 30 menit.

\section{Kegiatan Hasil Perencanaan Dan PelaksanaanPeningkatanKeterampila n Sosial Melalui Permainan Tradisional Babancakan di POS PAUD Melati 03.}

Data yang diperoleh dari penelitian ini merupakan pengembangan Keterampilan sosial anak POS PAUD Melati 03 yang diperoleh dari hasil observasi. Data observasi tersebut dilakukan untuk mengetahui Keterampilan sosial anak usia dini. Sedangkan, pemberian pembelajaran melalui permainan tradisional babancakan dilakukan untuk mengetaui kemampuan akhir pada anak setelah diberi pembelajaran.

\section{Hasil Pembelajaran Menggunakan Permainan Tradisional Babancakan}

1) Hasil Penelitian Sebelum Permainan Tradisional Babancakan (Anak lebih suka melakukan Kegiatan di ruang kelas daripada melakukan kegiatan diluar kelas )

Hasil observasi pada, menunjukkan bahwa dari 5 anak sebagai kasus yaitu Andrean, Alya , Dian, Rizki dan Rahmat semua belum suka melakukan kegiatan diluar sekolah dikarenakan sudah terbiasa didalam kelas sehingga belum mampumelakukankegiatanpembelajarandanmas ih memerlukanstimulasi untuk itu anak masih memerlukan bantuan Guru dan diperlukan diadakannya perbaikan dalam proses kegiatan yang lebih menarik.

2) Hasil Penelitian Sebelum Permainan

Tradisional Babancakan (Anak dapat

berinteraksi dengan lingkungan terdekat)

Hasil observasi menunjukkan bahwa dari 5 anak sebagai kasusyaitu Andrean, Alya, Dian, Rizki dan Rahmathanya 2 orang anak dapat mengikuti yaitu Rizki dan Rahmat. dan 3 orang anak

belum mampumelakukankegiatanpembelajarandanmas ih memerlukanstimulasi untuk itu anak masih memerlukan bantuan Guru dan diperlukan diadakannya perbaikan.

3) Hasil Penelitian Sebelum Permainan Tradisional Babancakan ( anak dapat menunjukkan keinginannya )

Hasil observasi menunjukkan bahwa 5 anak sebagai kasus yaitu Andrean, Alya, Dian, Rizki dan Rahmathanya 2 orang anak dapat mengikuti yaitu Rizki dan Rahmat dan 3 orang anak belum mampumelakukankegiatanpembelajarandanmas ih memerlukanstimulasianak masih merasa takut jatuh untuk itu anak masih memerlukan bantuan Guru dan diperlukan diadakannya perbaikan dalam proses kegiatan.

4) Hasil Penelitian Sebelum Permainan Tradisional Babancakan (Anak mengenal diri dan lingkungan terdekat ) 


\section{JURNAL CERIA}

ISSN : 2614-6347 (Print) 2614-4107 (Online)

Vol.1 | No.3 | Mei 2018

Hasil observasi menunjukkan bahwa 5 anak sebagai kasus yaitu Andrean, Alya, Dian, Rizki dan Rahmathanya 2 orang anak yaitu Andrean dan Rizki Anak dapat mampu melakukan semua kegiatan tanpa bantuan Gurudan 3 orang anak belum

mampumelakukankegiatanpembelajarandanmas ih memerlukanstimulasi untuk itu anak masih memerlukan bantuan Guru dan diperlukan diadakannya perbaikan dalam proses kegiatan.

5) Hasil Penelitian Sebelum Permainan Tradisional Babancakan ( Anak mampu menunjukkan kemandirian).

Hasil observasi menunjukkan bahwa 5 anak sebagai kasus yaitu Andrean, Alya, Dian, Rizki dan Rahmathanya 1 orang anak yaitu Rahmat Anak Mampu mampu memanjat dan bergantung tanpa bantuan Guru dan 3 orang anak belum mampumelakukankegiatanpembelajarandanmas ih memerlukanstimulasi untuk itu anak masih memerlukan bantuan Guru dan diperlukan diadakannya perbaikan dalam proses kegiatan.

6) Hasil Penelitian Sebelum Penggunaan Permainan Tradisional Babancakan (Anak bisa melakukan berbagai kegiatan sosial ).

Hasil observasi menunjukkan, bahwa 5 anak sebagai kasus yaitu Andrean, Alya, Dian, Rizki dan Rahmat 2 orang anak mampu anak mampu melakukan kegiatan percobaan yang dilakukan sekolah anak bisa melakukan kegiatan sosialtakut melakukan semua kegiatan tanpa bantuan Guru yaitu dan 3 orang anak belum

mampumelakukankegiatanpembelajarandanmas ih memerlukanstimulasi untuk itu anak masih memerlukan bantuan Guru dan diperlukan diadakannya perbaikan dalam proses kegiatan yang lebih menarik.

7) Hasil Penelitian Sebelum Penggunaan

Permainan Tradisional Babancakan

(Merespon terhadap beberapa nama teman bermain)

Hasil observasi menunjukkan bahwa 5 anak sebagai kasus yaitu Andrean, Alya, Dian, Rizki dan Rahmat 1 orang anak yaitu Rizki melakukan semua kegiatan tanpa bantuan Guru yaitu mampu merespon terhadap beberapa nama teman bermain belum mampu melakukan kegiatan pembelajaran dan masih memerlukan stimulasi untuk itu anak masih memerlukan bantuan Guru dan diperlukan diadakannya perbaikan dalam proses kegiatan yang lebih menarik.

8) Hasil Penelitian Sebelum Penggunaan

Permainan Tradisional Babancakan (Senang meniru apa yang dilakukan orang lain)

Hasil observasi menunjukkan bahwa 5 anak sebagai kasus yaitu Andrean, Alya, Dian, Rizki dan Rahmat 1 orang anak yaitu Rizki melakukan semua kegiatan tanpa bantuan Guru yaitu mampu meniru apa yang dilakukan orang lain dan 4 orang anak belum mampumelakukankegiatanpembelajarandanmas ih memerlukanstimulasi untuk itu anak masih memerlukan bantuan Guru dan diperlukan diadakannya perbaikan dalam proses kegiatan yang lebih menarik.

Berdasarkan Semua data observasi diatas, dapat disimpulkan bahwa pengembangan Keterampilan sosial menggunakan Permainan Tradisional Babancakan anak POS PAUD Melati 03 masih kurang. Data tersebut menunjukkan bahwa sebagian besar anak belum mampu melakukan semua kegiatan pembelajaran untuk itu masih sangat memerlukkan peran Guru untuk memberikan perbaikan dalam proses pengembangan Keterampilan sosial yang lebih menarik.

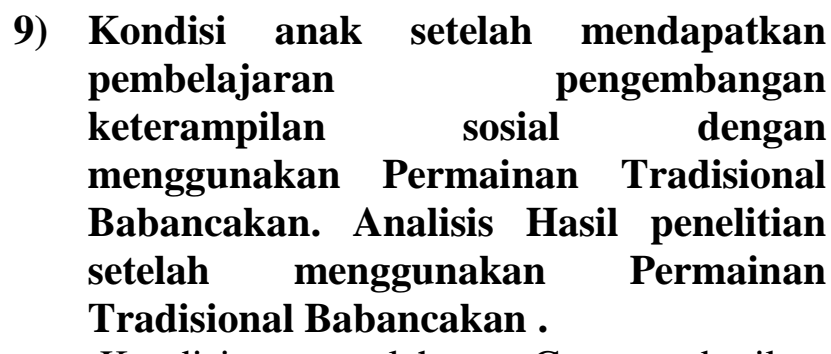

Kondisi setelah Gurumemberikan

Permainan Tradisional Babancakan untuk dijadikan upaya pengembangan Keterampilan sosial anak dapat terlihat melalui analisis hasil pembelajaran dengan beberapa item indikator pertanyaan yang dijadikan bahan observasi.

1) Hasil Penelitian Sebelum Permainan Tradisional Babancakan ( Anak lebih suka melakukan kegiatan diruangan kelas dari pada melakukan kegiatan diluar kelas ) 


\section{JURNAL CERIA}

ISSN : 2614-6347 (Print) 2614-4107 (Online)

Vol.1 | No.3 | Mei 2018

Hasil observasi pada, menunjukkan bahwa dari 5 anak sebagai kasus yaitu Andrean, Alya, Dian, Rizki dan Rahmat 5 orang anak sudah Baik anak mampu melakukan semua kegiatan tanpa bantuan Guru, yaitu anak suka bermain diluar kelas dan melakukan kegiatan diluar kelas (Permainan Tradisional Babancakan ) sesuai aturan. Setelah diadakannya perbaikan dalam proses kegiatan yang lebih menarik Permainan Tradisional Babancakan pengembangan Keterampilan sosial lebih baik dan anak lebih memahami serta bisa melakukan kegiatan dengan baik

2) Hasil Penelitian Sebelum Permainan Tradisional Babancakan (Mulai menunjukkan senang bermain dengan teman )

Hasil observasi pada, menunjukkan bahwa dari 5 anak sebagai kasus yaitu Andrean, Alya , Dian, Rizki dan Rahmat 4 orang anak yaitu Alya, Andrean, Dian dan Rizki sudah Baik anak mampu melakukan semua kegiatan tanpa bantuan Guru, yaitu anak mampu Mulai menunjukkan senang bermain dengan teman. Setelah diadakannya perbaikan dalam proses kegiatan yang lebih menarik Permainan Tradisional Babancakan pengembangan Keterampilan sosial lebih baik dan anak lebih memahami serta bisa melakukan kegiatan dengan baik sedangkan 1 orang anak masih memerlukan bantuan Guru dalam melakukan kegiatan.

3) Hasil Penelitian Sebelum Permainan

Tradisional Babancakan (Merespon terhadap beberapa nama teman bermain)

Hasil observasi pada, menunjukkan bahwa dari 5 anak sebagai kasus Yaitu Andrean, Alya, Dian, Rizki dan Rahmat 5 orang anak sudah Baik anak mampu melakukan semua kegiatan tanpa bantuan Guru, yaitu anak suka Merespon terhadap beberapa nama teman bermain. Setelah diadakannya perbaikan dalam proses yang lebih menarik Permainan Tradisional Babancakan pengembanganKeterampilan sosial lebih baik dan anak lebih memahami serta bisa melakukan kegiatan dengan baik
4) Hasil Penelitian Sebelum Permainan Tradisional Babancakan (Senang meniru apa yang dilakukan orang lain)

Hasil observasi pada, menunjukkan bahwa dari 5 anak sebagai kasus yaitu Andrean, Alya , Dian, Rizki dan Rahmat 4 orang anakyaitu Andrean, Alya, Dian dan Rizki sudah Baik anak mampu melakukan semua kegiatan tanpa bantuan Guru, yaitu anak suka Senang meniru apa yang dilakukan orang lain. Setelah diadakannya perbaikan dalam proses yang lebih menarik Permainan Tradisional Babancakan pengembangan Keterampilan sosial lebih baik dan anak lebih memahami serta bisa melakukan kegiatan dengan baik sedangkan 1 orang anak masih memerlukan bantuan Guru dalam melakukan kegiatan.

5) Hasil Penelitian Sebelum Permainan

Tradisional Babancakan (Mau menyapa teman)

Hasil observasi pada, menunjukkan bahwa dari 5 anak sebagai kasus yaitu Andrean, Alya, Dian, Rizki dan Rahmat 4 orang anak yaitu Andrean, Dian, Alya dam Rizki sudah Baik anak mampu melakukan semua kegiatan tanpa bantuan Guru, yaitu anak Mau menyapa temanketika melakukan Permainan Tradisional Babancakan sesuai aturan. Setelah diadakannya perbaikan dalam proses kegiatan yang lebih menarik Permainan Tradisional Babancakan pengembangan Keterampilan sosial lebih baik dan anak lebih memahami serta bisa melakukan kegiatan dengan baik sedangkan 1 orang anak masih memerlukan bantuan Guru dalam melakukan kegiatan.

6) Hasil Penelitian Sebelum Penggunaan Permainan Tradisional Babancakan (Menunjuk orang-orang yang terdekat).

Hasil observasi pada, menunjukkan bahwa dari 5 anak sebagai kasus yaitu Andrean, Alya, Dian, Rizki dan Rahmat 5 orang anak sudah Baik anak mampu melakukan semua kegiatan tanpa bantuan Guru, yaitu anak bisa Menunjuk orang-orang yang terdekat. Setelah diadakannya perbaikan dalam proses kegiatan Permainan Tradisional Babancakan yang lebih menarik untuk pengembangan Keterampilan sosial lebih baik dan anak lebih memahami serta bisa melakukan kegiatan dengan baik 
7) Hasil Penelitian Sebelum Penggunaan Permainan Tradisional Babancakan (Menyebutkan ciri-ciri dirinya)

Hasil observasi pada, menunjukkan bahwa dari 5 anak sebagai kasus yaitu Andrean, Alya , Dian, Rizki dan Rahmat 4 orang anak yaitu Rizki , Rahmat, Dian dan Andrean sudah Baik anak mampu melakukan semua kegiatan tanpa bantuan Guru, yaitu anak mampu Menyebutkan ciri-ciri dirinya rasa gembira ketika melakukan kegiatan diluar kelas sesuai aturan. Setelah diadakannya perbaikan dalam proses yang lebih menarik dengan Permainan Tradisional Babancakan pengembangan Keterampilan sosial lebih baik dan anak lebih memahami serta bisa melakukan kegiatan dengan baik sedangkan 1 orang anak masih memerlukan bantuan Guru dalam melakukan kegiatan.

Hasil observasi menunjukkan bahwa bahwa dari 5 anak yaitu Andrean, Alya, Dian, Rizki dan Rahmat sebagai kasus hamper keseluruhananak sudah baik anak mampu melakukan semua kegiatan tanpa bantuan Guru, yaitu anak dapat melakukan kegiatan Keterampilan sosial Setelah diadakannya perbaikan dalam proses yang lebih menarik salah satunya Permainan Tradisional Babancakan lebih baik dalam pengembangan Keterampilan sosial lebih baik dan anak lebih memahami serta bisa melakukan kegiatan dengan baik.

Berdasarkan Semua data observasi diatas, dapat disimpulkan bahwa pengembangan Keterampilan sosial anak POS PAUD Melati 03 sudah berhasil. Data tersebut menunjukkan bahwa sebagian besar anak sudah mampu melakukan semua kegiatan pembelajaran untuk itu peran Guru untuk memberikan perbaikan dalam proses kegiatan pengembangan Keterampilan sosial anak yang lebih menarik harus lebih ditingkatkan lagi.

Permainan Tradisional Babancakan dilakukananakyangbelumoptimaladalahanak masih ragu dan takut melakukan kegiatan.Sebagianbesar dikarenakananak belum jarang diajak kegiatan diluar sekolah Permainan Tradisional Babancakan yang diperkenalkan oleh Guru hanya beradapadakemampuancukup.
Dari hasil observasi yang telah dilakukan terdapat peningkatan yang cukup baikpadapengembangan Keterampilan sosialanakdalamsetiaptindakan padasetiap kegiatannya.

Hasilobservasidaripeningkatanpengembangan Keterampilan sosialanakdilihat denganmembandingkan hasilsetiapindikator penilaianyang dicapaibaikoleh anakpadaobservasiawaldenganhasildarisetiap kegiatan.

Peningkatan tidakhanyaterjadipadasetiapindikatorpenilaian,n amun setiapanakdiPOS PAUD Melati 03punmengalamipengembangan Keterampilan sosialmelalui kegiatan Permainan Tradisional Babancakan .

\section{KESIMPULAN}

Berdasarkan hasil pembahasan mengenai Permainan Tradisional sebagai dalam upaya peningkatan keterampilan sosial anak, maka dapat disimpulkan dari pertanyaan penelitian sebagai berikut :

1. Kondisi awal upaya peningkatan keterampilan sosial anak oleh guru relatif masih konvensional dalam hal tersebut dikatakan hasil karya hanya terbatas pada senam dan permainan yang ada kaitannya dengan dengan keterampialn sosial.

2. Proses permainan tradisional ditempuh melalui tahap-tahap pelaksanaan yang sederhana tidak rumit mudah diikuti oleh anak tanpa menggurui yang berarti tahaptahap tersebut melalui tahap-tahapan menyusun RKH pelaksanaan terpecah 3 tahap: Inti kegiatan, Kegiatan akhir, refleksi kegiatan

3. Hasil permainan tradisional upaya meningkatkan keterampilan sosial telah memberikan kontribusi yang seperti dalam pengembangan keterampilan sosial anak pada umumnya terutama bila keterampilan sosial kondisi tubuh dan latihan, konsentrasi, berfikir kreatif walaupun masih ditemukan sebagian kecil anak yang menunjukkan kadar partisipasi permainan tradisional babancakan. 


\section{JURNAL CERIA}

ISSN : 2614-6347 (Print) 2614-4107 (Online)

Vol.1 | No.3 | Mei 2018

\section{DAFTAR PUSTAKA}

Ahmadi, Adi dan Widodo. 2005. Psikologi

Belajar. Jakarta: Rineka Cipta.

Armstrong, Thomas. 2003. Smart Baby's Brain. Jakarta: Prestasi Pustaka.

Champbell, Linda dkk. 2002. Multiple Intelligences, Metode Terbaru Melesatkan Kecerdasan. Depok: Inisiasi Press.

Gardner, H. 2000. Frames of Mind: The Theory of Multiple Intellegences (Terjemahan).Jakarta: Gramedia.

Goleman, Daniel. 2007. Sosial Intellegence (Edisi Indonesia). Jakarta: Gramedia.

Gunawan, Adi W. 2004. Genius Learning Strategy. Jakarta: Gramedia.

Reni Akbar, dkk. 2001. Keberbakatan Intelektual. Jakarta: Grasindo.

Robert, A. Baron. 2002. Psikologi Sosial. Jakarta: Erlangga.

Sadirman.2006. Interaksi dan Motivasi Belajar Mengajar.Jakarta: Raja Grafindo Persada.

Safaria, T. 2005. Interpersonal Intellegence. Yogyakarta: Amara Books.

Slameto. 2003. Belajar dan Faktor-Faktor yang Mempengaruhi. Jakarta: Rineka Cipta.

Syah, Muhibbin. 2001. Psikologi Belajar. Jakarta: Logos Wacana Ilmu. 